\title{
Law's Echo Lies In
}

\author{
Trish Salah
}

Law's Echo Lies In constitue une réflexion sur le lien qui existe entre la reconnaissance et la honte, les viscissitudes des remerciements et le lieu où « la loi prend congé ».

A girl on the side of the sign. Proposing to a ghost, her orders.

See how she breaks the rain. The flood itself. She said.

Seems I ever kissed you. U. Oh, for shame, oh unseemly

Do you see you kiss, your kiss, how it is yours?

Very much of you, very much, thank you. Thanks too.

(Law's capacity for abundant gratitude.)

How is it in that doorway? Knocking sounds, a trace

Is there, our hollow?

I didn't suspect God, it didn't expect you.

Behind the door, the door itself. Echoes.

Was it Echo? Where, sere ardour, oh

Law takes her leave here.

Mind the bloody bodies strewn about the park. Mind, the bloody river, knee deep, we're wading.

You were a suspician in the door who wanted to want to be

Not in accusation, not a flood her ardour when it [by this it was her oracular you when you came here $I$, waterlike, breaking the word for rain, broke kisses run to ground - how arch it seems]

Oracular, the questioner returned, and her, her very dear and own, whistles "Law?"

Well, Law can not help but pose:

"Do you flood this day, as I do, Echo? Where will we come again to that door? Was it flood?"

Echo takes recourse in her whispers. Echo in her quicksand. To shame shame. 


\section{Tessera}

Echo fed up to the seme, the seams like, archest of kisses. Her deacon, her Law fed on what? Of her, of what nourishment? In flood, she watered her own oh own hole, was hoping for a little respite. Mind it like white powder, offspring of bones. Mind, the white clouds.

Knee deep now, we're wading.

Echo makes her promise. Said:

No more suspician, Law. No corpses here. My heavenly body has had it. This Echo's got her own word for shame, her portal to the future. The god's kiss it, waterling, oracalurlike, you.

If you choose to end here, if you choose to, the rain as you know it will drown your vast and hollow -

And again, Law, you're rich run off, a sweetness of meat, married, in the run off.

I will not complain when.

Buried and no mourners come to play. 